\title{
The Evident Role of Clouds on Phytoplankton Abundance in Antarctic Coastal Polynyas
}

\author{
Hyoung Sul La ${ }^{1}$ and Keyhong Park ${ }^{1,2, *}$ \\ ${ }^{1}$ Division of Polar Ocean Environment, Korea Polar Research Institute, Incheon, South Korea \\ ${ }^{2}$ Department of Ocean Sciences, Inha University, Incheon, South Korea
}

Received 15 July 2015, revised 26 November 2015, accepted 30 November 2015

\begin{abstract}
High-level primary production (PP) sustainability in the Antarctic coastal polynyas has not been adequately addressed. We investigated the relationship between the Antarctic coastal polynyas phytoplankton biomass (as reflected by Chl- $a$ ) and the cloud cover, which dominantly influences the light conditions. Phytoplankton biomass in Antarctic coastal polynyas showed a robust correlation with the photosynthetically active radiation (PAR) and the cloud fraction. However, a different relationship was observed between the phytoplankton biomass and the PAR. This relationship depended on both the ultraviolet (UV) radiation and the geographical location of the coastal polynyas. High intensity UV radiation is suspected to be an inhibitor of phytoplankton biomass. This indicates that the phytoplankton biomass is effectively limited by light intensity, which can be reduced by clouds, particularly mid- and high-level clouds, but it is not limited by light under high-level UV radiation exposure conditions.
\end{abstract}

Key words: Antarctic, Coastal polynya, Chlorophyll- $a$, Cloud cover, Ultraviolet radiation, PAR

Citation: La, H. S. and K. Park, 2016: The evident role of clouds on phytoplankton abundance in Antarctic coastal polynyas. Terr. Atmos. Ocean. Sci., 27, 293-301, doi: 10.3319/TAO.2015.11.30.01(Oc)

\section{INTRODUCTION}

The Antarctic coastal polynyas are essential sentinels of the Southern Ocean ecosystem because they are the first polar marine system to be exposed to increasing solar radiation during springtime. They are clearly associated with the complex ocean and atmosphere processes, such as the ocean to atmosphere heat fluxes (Minnett and Key 2007), $\mathrm{CO}_{2}$ exchange (Sweeney et al. 2000), the carbon cycle (Becquevort and Smith 2001), the ocean circulation (Buffoni et al.2002), biological carbon pump, and high primary production (PP) (Arrigo and van Dijken 2003; Lee et al. 2012).

Phytoplankton in the Southern Ocean are major drivers of global carbon cycling, accounting for $\sim 2 \mathrm{PgC}$ of annual PP (Yager et al. 2012). Phytoplankton growth is governed by the availability of light and nutrients with other factors such as wind, precipitation, and regional climatic conditions influencing the upper water column (Mitchell and HolmHansen 1991; Alderkamp et al. 2011; Venables et al. 2013). Particularly, PP in coastal polynyas around the Antarctic

\footnotetext{
* Corresponding author

E-mail:keyhongpark@kopri.re.kr
}

continent is approximately four-fold higher than that in all of the Southern Ocean laying over $50^{\circ} \mathrm{S}$ (Yager et al. 2012). The light condition has been considered one of the major factors that strongly influence Southern Ocean phytoplankton productivity (Venables and Moore 2010). Most studies on phytoplankton productivity around the Southern Ocean focused principally on the effects of different light conditions (Robinson et al. 1997; Arrigo and van Dijken 2003; Van Leeuwe et al. 2005; Kropuenske et al. 2009; Arrigo et al. 2010). Light intensity over the Southern Ocean depends strongly on cloud distribution with clouds frequently extending over the polynyas.

The cloud fraction in polar regions has a major effect on the solar radiation flux that reaches the sea surface. The cloud fraction specifically influences the incidence of photosynthetically active radiation (PAR) that considerably influences phytoplankton growth. The amount of cloud cover, the types of clouds, the precipitation and the surface temperature all influence the amount of ground level ultraviolet (UV) radiation by absorbing and reflecting the solar radiation (Josefsson and Landelius 2000). However, there have 
been no investigations that analyzed the direct influence of cloud cover on phytoplankton abundance.

In this paper, we assessed the potential importance of the cloud fraction as a major controlling factor for the phytoplankton biomass in Antarctic coastal polynyas as well as the suggested cloud cover as an integrated parameter representing the overall light conditions (e.g., PAR and UV). Antarctic coastal polynyas are the ideal laboratory to evaluate variations in phytoplankton biomass caused by changes in cloud cover because they are biological hot spots in the Southern Ocean and have shown diverse amounts of chlorophyll $a$ (Chl- $a$ ) and PP (Arrigo and van Dijken 2003; Arrigo et al. 2010).

\section{METHODS}

We analyzed the relationship between cloud fractions over the Antarctic coastal polynyas and the proxies for phytoplankton biomass: Chl- $a$ and PP.

The Chl- $a$ and PP for 37 coastal polynyas are available from Arrigo and van Dijken (2003) (Figs. 1a and b). Briefly, we used the 5-year January Chl- $a$ and PP mean for each coastal polynya because more than $50 \%$ of the peak PP occurs in January. The Chl- $a$ information was taken from the SeaWiFS (Sea-Viewing Wide Field-of-View Sensor) 8-day Level 3 binned files using the OC4v4 algorithm (O'Reilly et al. 1998). The PP was determined using a function of the spectral downwelling irradiance, water temperature and
Chl- $a$, as developed by Arrigo et al. (1998).

We derived information on PAR and cloud fractions using the Modern-Era Retrospective analysis for Research and Applications (MERRA) climatology developed by NASA (Rienecker et al. 2011). The horizontal resolution of the data sets are $1^{\circ} \times 1.25^{\circ}$, and each parameter was calculated for the January monthly mean from 1997 to 2001 over the predefined coastal polynyas. We used the 5-year mean of each data set to minimize any influence of seasonal sea ice dynamics or interannual variation in environmental conditions on phytoplankton biomass. The interannual variability of the external factors contains influence of El Niño Southern Oscillation (ENSO) and Southern Annual Mode (SAM).

The MERRA PAR product has been successfully used to investigate biogeochemical aspects of various ecosystems (Yuan et al. 2011; Cai et al. 2014; Sindelarova et al. 2014; Yue et al. 2015). Additionally, we compared it with observational PAR obtained by the SeaWiFS satellite from 1998 to 2001 for all 37 polynyas. In $81 \%$ of the polynyas the correlations $(r)$ between the two data sets were greater than 0.25 and the mean correlation was $0.54 \pm 0.45$. Thus, we believe that the MERRA PAR product has a robust positive correlation with the observations over Antarctic coastal polynyas during our investigation period (1997 - 2001).

Because Naud et al. (2014) reported that the MERRA data set significantly underestimates cloud fractions over the Southern Ocean, we used both MERRA and ERA-interim (Dee et al. 2011) cloud fraction data sets in the analyses
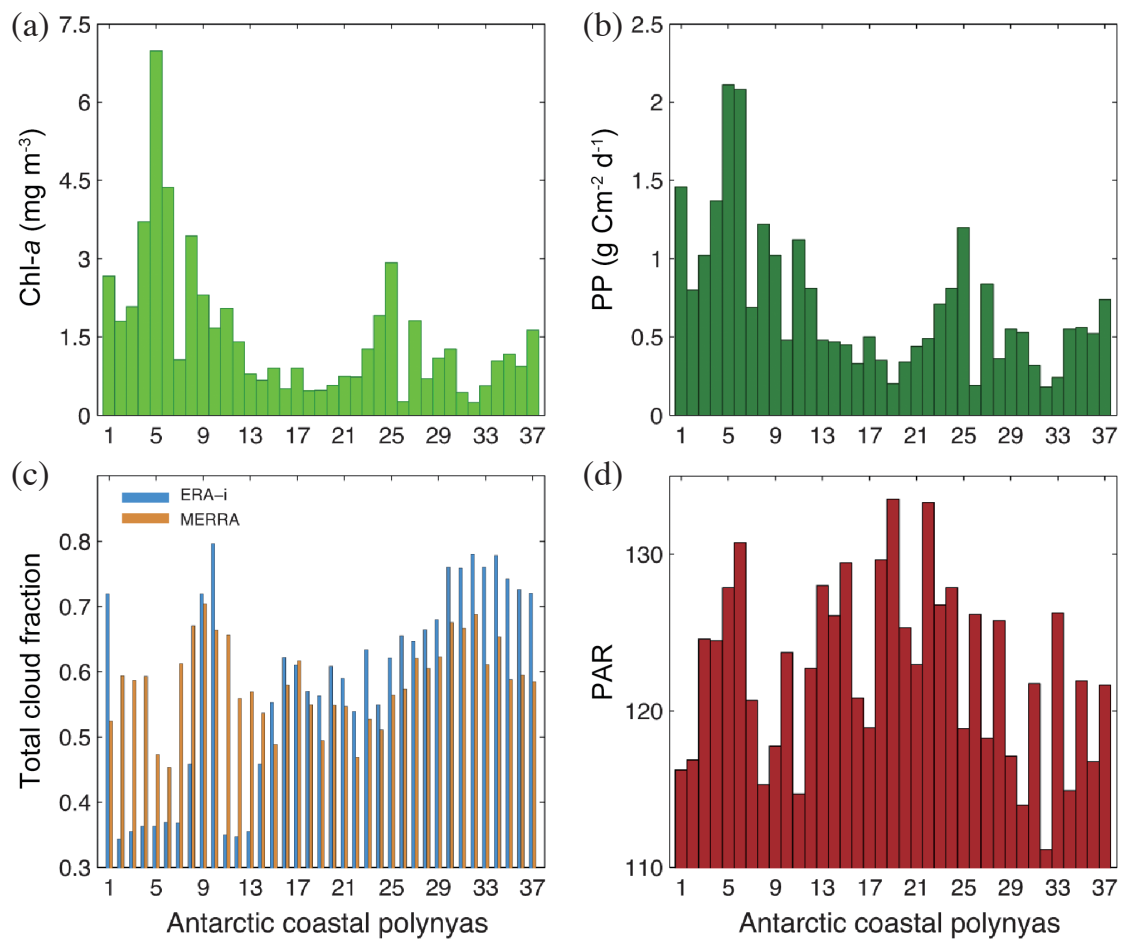

Fig. 1. Histograms of (a) Chl- $a$ (green bars), (b) PP (red bars), (c) total cloud fractions (blue bars: ERA-interim, orange bars: MERRA), and (d) PAR (red bars) in the 37 Antarctic coastal polynyas. (Color online only) 
(Fig. 2). The horizontal resolution of the ERA-interim cloud fractions is $0.75^{\circ} \times 0.75^{\circ}$ and the data subset periods are the same as those from the MERRA cloud. Although the MERRA cloud fractions underestimates over the Southern Ocean, the cloud fractions over the Antarctic coastal region, where most polynyas are distributed, exhibited similar distributions in the two data sets (MERRA and ERA-interim), except for some polynyas in West Antarctica.

The MERRA and ERA-interim data provides total cloud fractions and also cloud fractions at three different heights. Hence, four different kinds of cloud fraction information from each climatology data set enabled us to examine the cloud height effect on the phytoplankton biomass. Based on the atmospheric pressure, the cloud fraction height data are defined as low-level cloud (1 - 0.8 sigma; sigma = pressure / surface pressure), mid-level cloud (0.8 - 0.45 sigma), highlevel cloud ( $<0.45$ sigma) in ERA-interim, and low-level cloud (> $700 \mathrm{hPa})$, mid-level cloud (700 - $400 \mathrm{hPa})$, highlevel cloud (<400 hPa) in MERRA (Fig. 2).

\section{RESULTS AND DISCUSSION}

We found large variations in cloud cover over the Southern Ocean and Antarctic coastal regions (Fig. 2). The latitudinal gradient of the total cloud fraction is classified by approximately $65^{\circ} \mathrm{S}$, which represents the highest cloud fraction. Low-level clouds were distributed mainly over high latitudes (above $65^{\circ} \mathrm{S}$ ), where most coastal polynyas are located. The
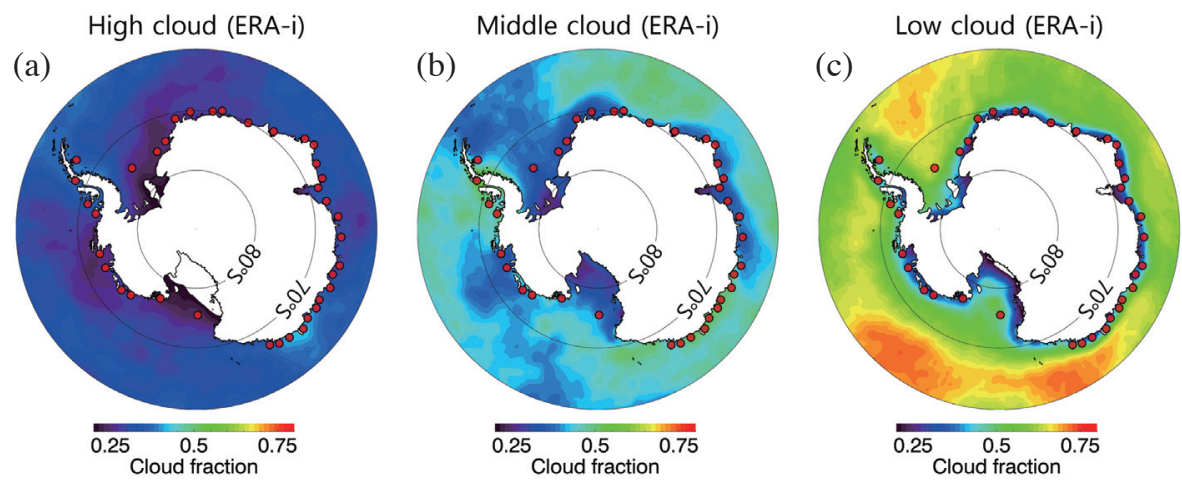

High cloud (MERRA)

(d)

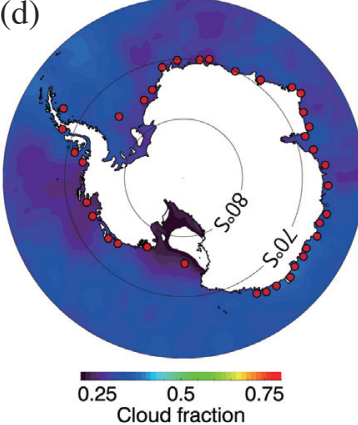

Total cloud (ERA-i)

(g)

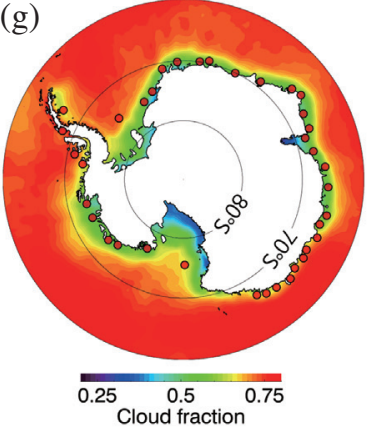

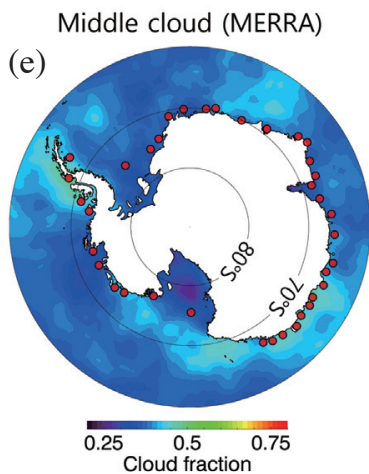

Total cloud (MERRA)

(h)

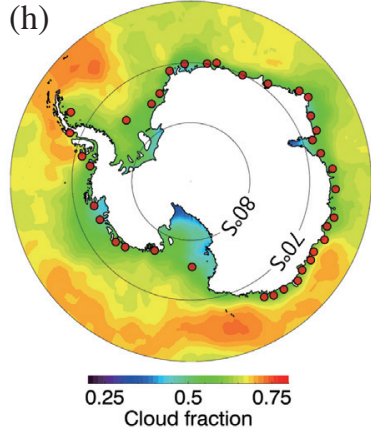

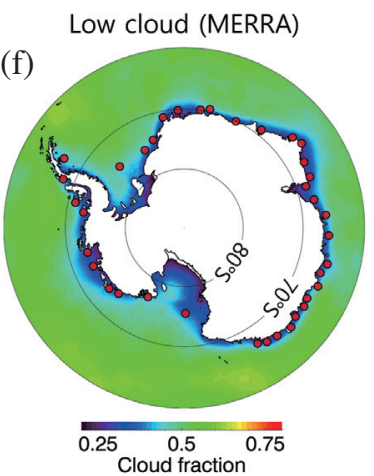

Antarctic coastal polynyas

(i)

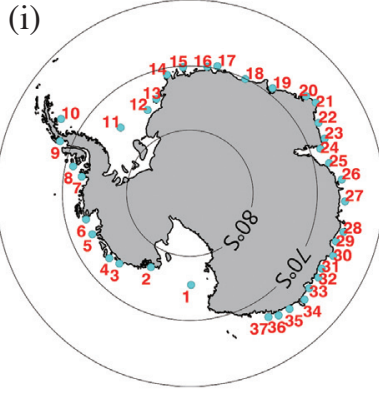

Fig. 2. Maps displaying the locations of the 37 Antarctic coastal polynyas (Arrigo and van Dijken 2003) and the cloud fractions. The 5-year (1997 - 2001) January mean cloud fractions of high-, mid-, and low-level clouds, as defined by the ERA-interim and MERRA climatologies are displayed in (a) - (c) and (d) - (f) respectively. The total cloud fractions are displayed in (g): ERA-i and (h): MERRA. The 37 coastal polynyas around the Antarctic continent are presented in (i). Note, the definition of cloud height is different between ERA-i and MERRA (see Fig. 3). (Color online only) 
total cloud fractions around coastal polynyas varied from 0.34 - 0.80 with ERA-interim, and from 0.45 - 0.70 with MERRA. They also show that the total cloud fractions over the Western Antarctic continent were relatively smaller than those over the Eastern Antarctic continent. The cloud fractions varied by cloud height (low-, mid-, and high-level clouds) as well. The mean cloud fractions over the polynyas were $0.58,0.34,0.34$, and 0.21 (ERA-interim) and 0.58, 0.32, 0.36, and 0.24 (MERRA) for total, low-, mid-, and high-level clouds, respectively. High-level clouds are generally more transparent than lowand mid-level clouds which are denser than the high-level clouds (Josefsson and Landelius 2000).

The Chl- $a$ in Antarctic coastal polynyas, which reflects the spatial variation in phytoplankton biomass, ranged from $0.2-6.9 \mathrm{mg} \mathrm{m}^{-3}$, with the highest value appearing in the Amundsen Sea polynya (Fig. 1a). The mean Chl- $a$ of the coastal polynyas of West Antarctica was $2.9 \mathrm{mg} \mathrm{m}^{-3}$, thus three times higher than that of the coastal polynyas of East Antarctica.

The total Antarctic coastal polynyas cloud fractions exhibited high spatial variation in response to the PAR. A strong negative correlation was found between the total cloud fraction and the PAR $(r=-0.7, p<0.01)$, indicating that greater cloud fractions were associated with lower PAR conditions, especially around polynyas in the Antarctic Peninsula (8 - 10) and Henry Bay (30 - 32) polynyas (Fig. 1b).

Because notable influences of total cloud fraction to the solar radiation have been analyzed by previous studies (Bais et al. 1993), it may be useful to understand the changes in light conditions by analyzing the cloud fractions at different heights' (Fig. 3). The variation in the total cloud effect was clearly associated with the cloud fractions of three different heights and was strongly correlated with the variation in both the mid- and low-level cloud fractions $(r=0.8, p<0.01)$. Thus, this indicates that mid- and low-level clouds predominantly effect the variation in PAR.
Along with temperature and dissolved nutrients, light is considered the "master" abiotic property controlling the phytoplankton biomass in the ocean. However, we found that the Chl- $a$ and PAR did not exhibit a meaningful relationship (Figs. 1a and 3). Light clearly did not limit phytoplankton growth in the Antarctic coastal polynyas because the photon flux densities during January were greater than those needed to saturate photosynthesis (Hiscock et al. 2008). In spring and summer the sea ice is much thinner than in winter, and $89 \%$ of the coastal polynyas reach their peak open water extent between January and March (Arrigo and van Dijken 2003). Even if one-half of the surface irradiance was attenuated by ice, enough light would penetrate to force photosynthesis (Smith et al. 2000).

In contrast, we found a negative correlation between Chl- $a$ and the high-level cloud fraction $(r=-0.3, p<0.05)$. We suspect that the high-level cloud cover affects the extent of UV radiation. UV is readily scattered or absorbed by high-level clouds before reaching the mid- and low-level clouds, while PAR is affected mostly by mid- and low-level clouds because the UV wavelength $(\sim 300 \mathrm{~nm})$ is shorter than that of PAR $(\sim 500 \mathrm{~nm})$. Also, UV radiation is known to cause damage in a variety of marine organisms (Karentz 1991). It can reduce the photosynthetic rate (Helbling et al. 2003), and damage cellular components such as proteins (Sass et al. 1997) and DNA molecules (Buma et al. 2003). In particular, phytoplankton photosynthesis in surface waters is strongly affected by UV radiation, which has deleterious effects on nutrient uptake (Fauchot et al. 2000), growth (Villafañe et al. 2003), toxin production, fatty acid composition (Goes et al. 1994), and species composition (Beardall et al. 2009; Fu et al. 2012). Photosynthesis of Antarctic phytoplankton is also inhibited by ambient UV radiation (Neale et al. 1998), and thus UV is associated with adverse impacts on PP in near-surface waters in the marginal ice zone (Smith et al. 1992).
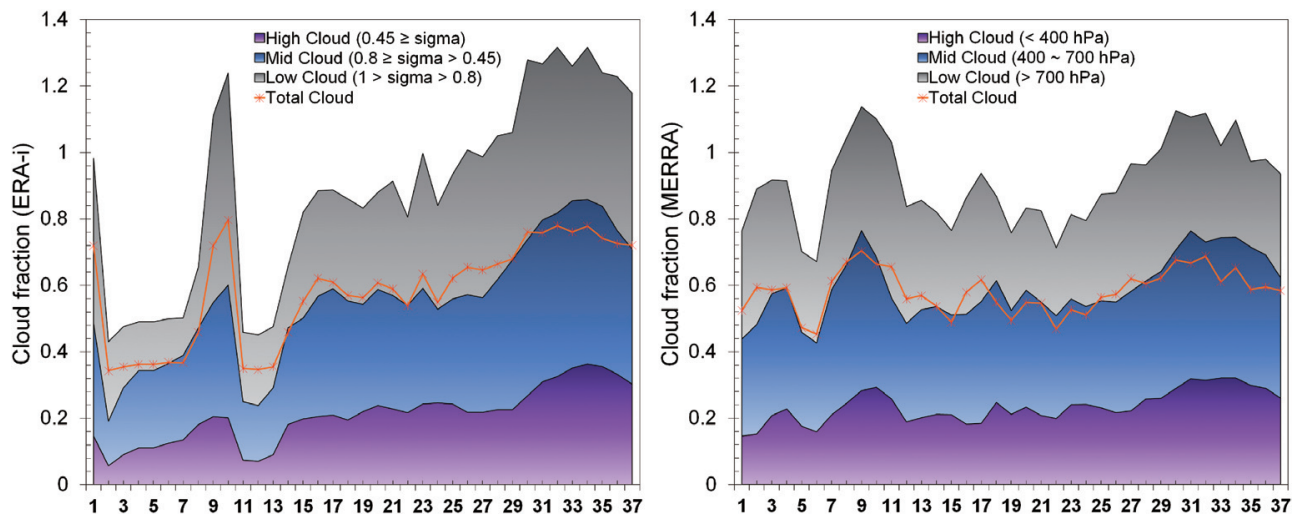

Fig. 3. Cloud fractions of high-level clouds (purple), mid-level clouds (blue), and low-level clouds (grey) around the Antarctic coastal polynyas. The left and right panels were derived using ERA-interim and MERRA, respectively. The definition of cloud heights in ERA-interim is $0.45 \geq$ sigma (high), $0.8 \geq$ sigma $>0.45$ (middle), and $1>$ sigma $>0.8$ (low); sigma $=$ (pressure / surface pressure) and that in MERRA is $400 \mathrm{hPa} \geq \mathrm{pressure}$ (high), $700 \mathrm{hPa} \geq$ pressure $>400 \mathrm{hPa}$ (middle), and pressure $>700 \mathrm{hPa}$ (low). (Color online only) 
The 5-year erythemal UV radiation average around the Southern Ocean clearly exhibited spatial variations (Fig. 4). Generally, the UV levels over polynyas located in the Atlantic or Indian Ocean sector are stronger than those over polynyas in the Pacific Ocean sector. Because sea ice and snow cover as well as cloud cover influence the scattering and reflection of UV, the strength of surface UV may have a nonlinear relationship with the presented erythemal UV. Qualitative analysis is however possible using 5-year mean values. Phytoplankton in coastal polynyas in the Atlantic or Indian Ocean sector is exposed to stronger UV radiation in January. Thus, different from the PAR condition which barely limits PP in polynyas, the phytoplankton biomass could present different biological response patterns with analyses combined with a high-level UV condition.

We categorized the coastal polynyas into two geographically continuous groups to explore the phytoplankton response to PAR under different UV radiation conditions. Group 1 contained coastal polynyas 1 - 10 and 29 - 37 and
Group 2 contained coastal polynyas 11 - 28. These groups were primarily separated based on the different UV radiation strengths over the polynyas (Fig. 4). In addition, any statistical bias raised by a difference in the sample number was minimized by choosing a similar number of polynyas in each group. Group 1 polynyas are placed in relatively low UV conditions $\left(62.8 \pm 14.1 \mathrm{~mW} \mathrm{~m}^{-2}\right)$ and Group 2 polynyas are placed in relatively high $\mathrm{UV}$ conditions $\left(70.2 \pm 17.6 \mathrm{~mW} \mathrm{~m}^{-2}\right)$.

Figure 5 shows the different relationships between the phytoplankton biomass and PAR for each group. Group 1 polynyas (red dots) showed a robust positive correlation between the phytoplankton biomass and PAR ( $r=0.51, p<0.05)$, whereas Group 2 polynyas showed strong negative correlations $(r=-0.56, p<0.05)$ (Table 1$)$. The phytoplankton biomass of Group 2 was limited from $0.2-3 \mathrm{mg} \mathrm{m}^{-3}$, whereas that of Group 1 was more broadly distributed from $0.2-7 \mathrm{mg} \mathrm{m}^{-3}$. The positive overall correlation in Group 1 was clearly influenced by the two high-level Chl- $a$ polynyas (Fig. 5 left panel), and thus the exclusion of

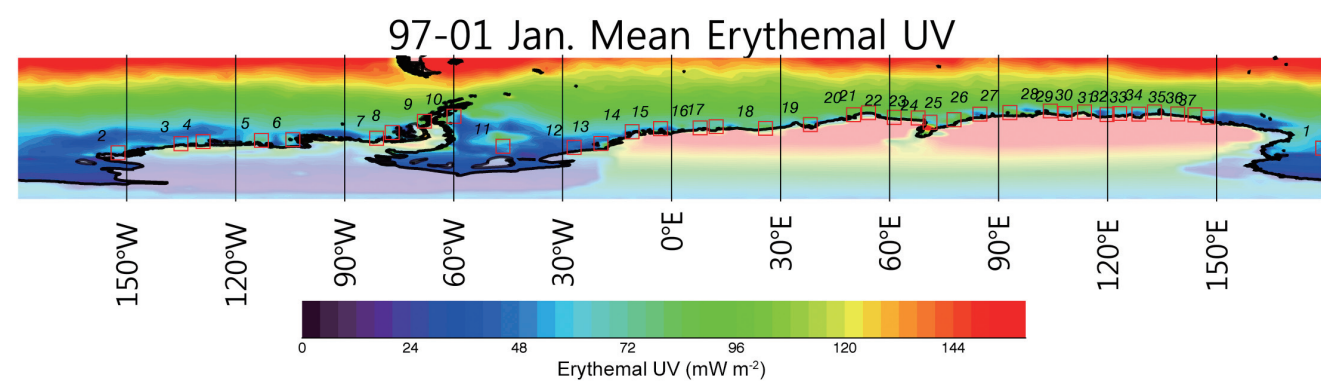

Fig. 4. Map of ultraviolet (UV) radiation (MERRA reanalysis climatology) around the Antarctic continent. (Color online only)
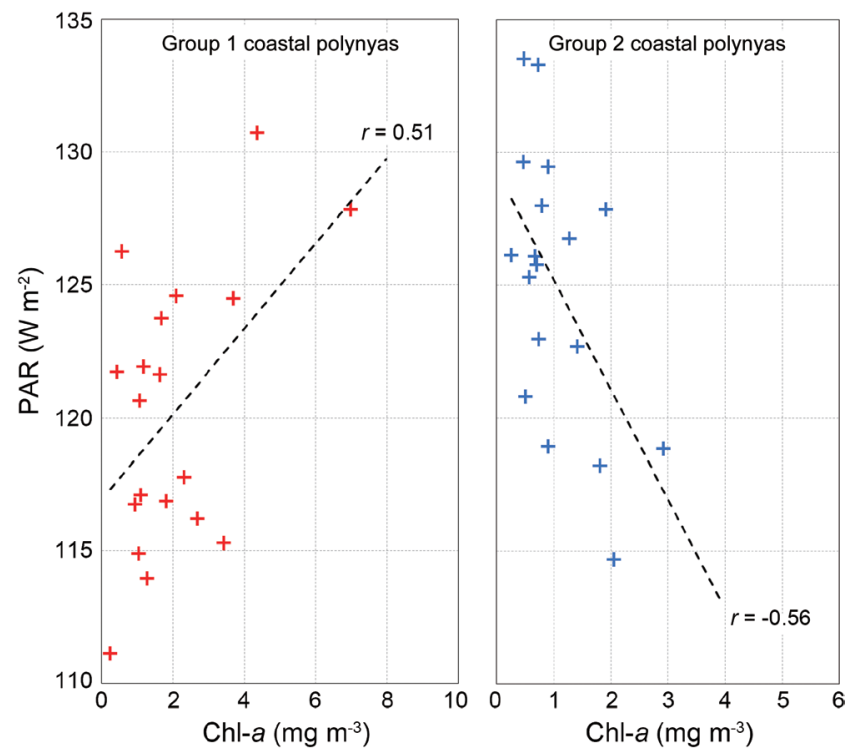

Table 1. Linear regression $(\mathrm{PAR}=\mathrm{b}+\mathrm{a} * \mathrm{Chl}-a)$ results that compare the phytoplankton biomass (Chl- $a$ ) and the PAR. Coefficients, error estimates (standard error, SE), and the $p$ value for the response of the PAR to the phytoplankton biomass.

\begin{tabular}{cccccc}
\hline & & coefficient & SE & $\boldsymbol{t}$ & $\boldsymbol{p}$ \\
\hline \multirow{2}{*}{ Group 1 } & slope (a) & 1.6 & 0.6 & 2.4 & $<0.05$ \\
& y-intercept (b) & 116.7 & 1.7 & 67.9 & $<0.01$ \\
\hline \multirow{2}{*}{ Group 2 } & slope (a) & -3.2 & 1.6 & -2.1 & $<0.05$ \\
& y-intercept (b) & 128.8 & 1.9 & 68.4 & $<0.01$ \\
\hline
\end{tabular}

Fig. 5. Scatter plots of PAR vs. Chl- $a$ in the 37 Antarctic coastal polynyas. Group 1 (red crosses) includes values for polynyas 1 - 10 and 29 - 37, and Group 2 (blue crosses) represents values for polynyas 11 - 28. (Color online only) 
these two will present no correlation. Phytoplankton photosynthesis is generally considered to have a strong light dependence. Thus, a positive correlation between the PAR and phytoplankton biomass is expected in regions with limited light. If light is not a limiting factor for phytoplankton growth, no correlation will be found. This implies that, under low UV radiation, the phytoplankton biomass increases with or is insensitive to enhanced light intensity in coastal polynyas (Group 1). However, under high UV radiation the phytoplankton biomass is suppressed by $\mathrm{UV}$ radiation in the coastal polynya (Group 2).

In Group 1 polynyas, the phytoplankton biomass was robustly associated with the total cloud fraction and the cloud fractions of high- and mid-level clouds (Fig. 6). This presents a trend opposite that between the total cloud fraction and PAR, as shown in Figs. 1c and d. Also, the relationships analyzed by either ERA-interim or MERRA climatology produced similar results. Clouds play a role in blocking the PAR incidence arriving at the sea surface, which affects the phytoplankton biomass. As shown in Fig. 6, the correlations between Chl- $a$ levels and the cloud fractions of mid- and high-level clouds were significant, which implies that the influence of such clouds on phytoplankton is more important than that of low-level clouds. Meanwhile, even if the phytoplankton biomass of Group 2 showed a strong negative relationship with the PAR, Chl- $a$ did not relate to

(a)

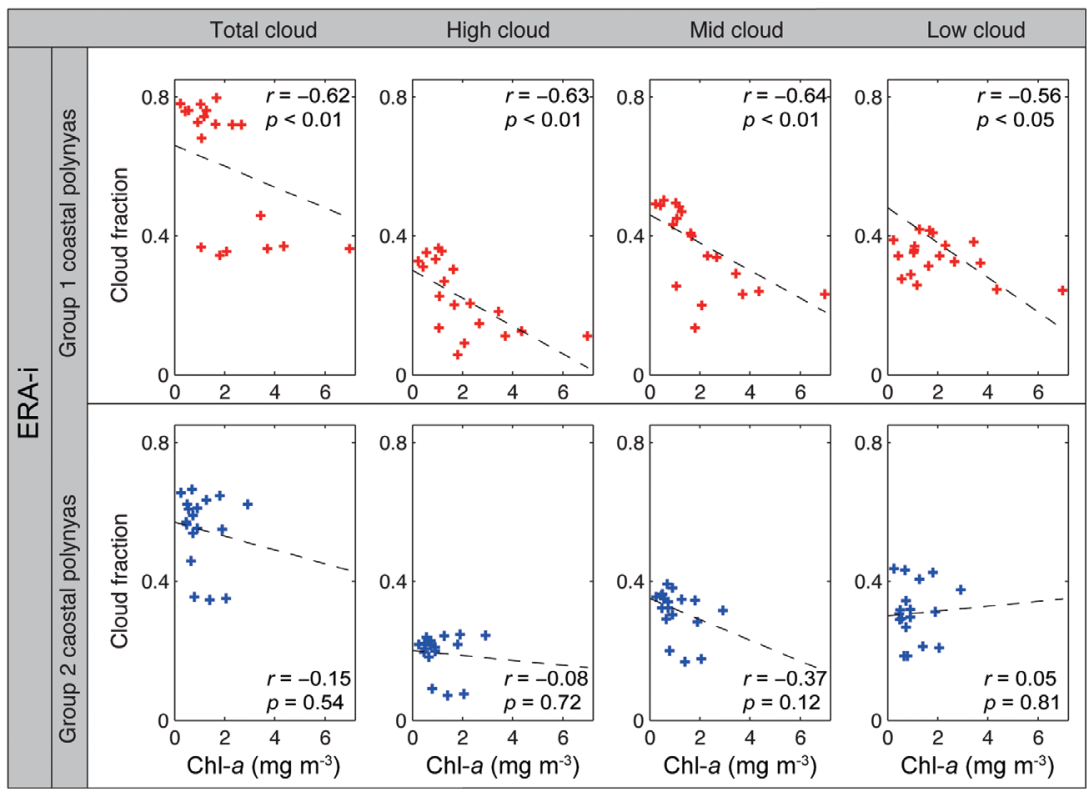

(b)

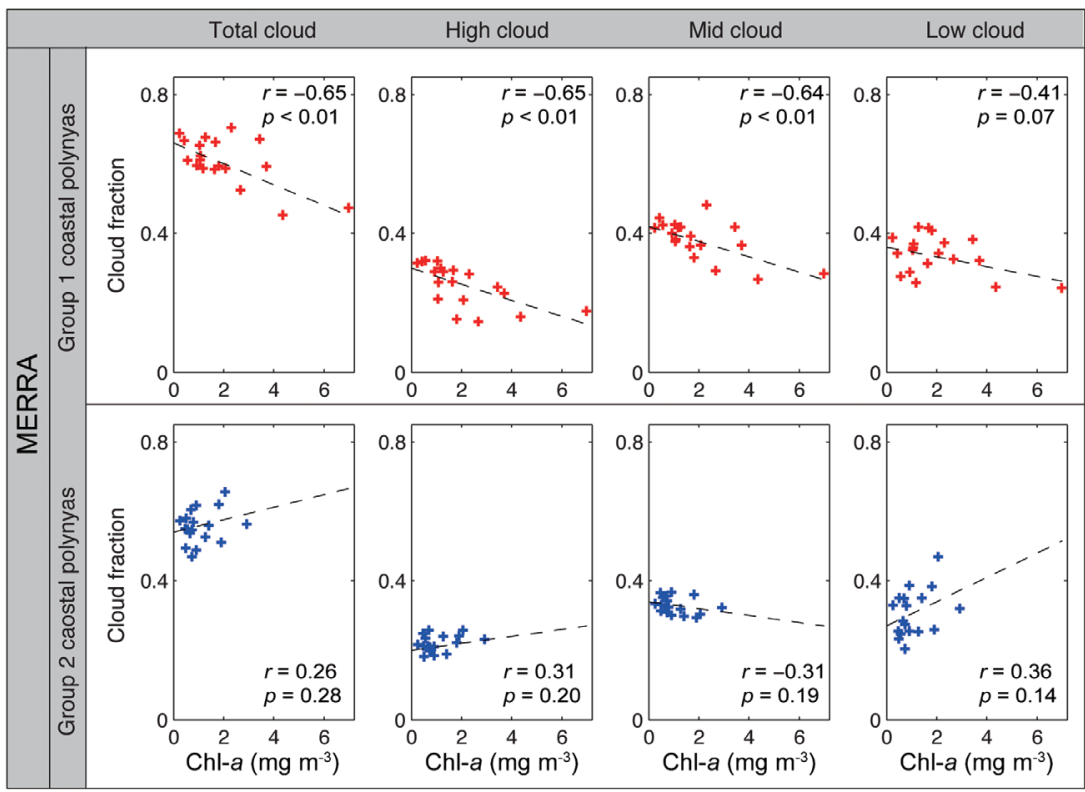

Fig. 6. The relationships between Chl- $a$ and total, high-, mid-, and low-level cloud fractions in 37 Antarctic coastal polynyas analyzed using (a) ERA-interim and (b) MERRA data. The red and blue crosses indicate the data from Groups 1 and 2, respectively. (Color online only) 
the cloud fractions. Thus, the lack of relationship between Chl- $a$ and cloud fractions in Group 2 polynyas suggests that the adverse effects of UV radiation overwhelm the influence of clouds on the PAR.

\section{CONCLUDING REMARKS}

In this study, we explored a novel hypothesis that cloud fractions can be an important factor that regulates phytoplankton production in the high-latitude coastal polynyas in the Southern Ocean. The high intensity light associated with low cloud cover can significantly increase phytoplankton production in Antarctic coastal polynyas. Antarctic coastal polynyas can be referred to as a high nutrient and high chlorophyll environment (HNHC). They have often been influenced by the availability of iron from coastal sediments/ upwellings (Tagliabue et al. 2009), sea ice (Edwards and Sedwick 2001), dust (Jickells et al. 2005), iceberg-rafted debris (Raiswell and Canfield 2012), and subglacial meltwater that is discharged from the ice sheet (Wadham et al. 2010). Considering the high-nutrient concentration and the availability of iron, the light condition (both PAR and UV) might be a controlling factor for phytoplankton production in these areas. In addition, our results suggest that spatially sustained high intensity UV radiation would limit the phytoplankton biomass. Therefore, UV radiation and cloud fractions at different cloud heights could be essential factors that explain the phytoplankton biomass in Antarctic coastal polynyas.

This study thus suggests that cloud cover and its height can be used as an effective factor to estimate the PP of polynyas in the Southern Ocean. Cloud cover data closely influences and represents the light condition in the polynyas, which simultaneously hinders the amount of PAR and UV that reach the surface. These effects vary depending on the location of the polynya and the heights of the overlying clouds. Thus, highly productive polynyas can be found at locations placed under optimal cloud cover conditions.

Acknowledgements All data sets used in this paper are available upon request to the corresponding author (keyhongpark@kopri.re.kr). The authors thank S.Y.Ha and the Two Anonymous Reviewers for their constructive comments. This research was supported by Korea Polar Research Institute grants (PP16020, PE16040, and PM16040) and K. Park was also supported by the Polar Academic Program (PD15010) and PM16060 of KOPRI.

\section{REFERENCES}

Alderkamp, A. C., V. Garcon, H. J. W. de Baar, and K. R. Arrigo, 2011: Short-term photoacclimation effects on photoinhibition of phytoplankton in the Drake Passage (Southern Ocean). Deep-Sea Res. Part I-Oceanogr.
Res.Pap., 58,943-955, doi: 10.1016/j.dsr.2011.07.001. [Link]

Arrigo, K. R. and G. L. van Dijken, 2003: Phytoplankton dynamics within 37 Antarctic coastal polynya systems. J. Geophys. Res., 108, doi: 10.1029/2002JC001739. [Link]

Arrigo, K. R., A. M. Weiss, and W. O. Smith Jr., 1998: Physical forcing of phytoplankton dynamics in the southwestern Ross Sea. J. Geophys. Res., 103, 10071021, doi: 10.1029/97JC02326. [Link]

Arrigo, K. R., M. M. Mills, L. R. Kropuenske, G. L. van Dijken, A. C. Alderkamp, and D. H. Robinson, 2010: Photophysiology in two major Southern Ocean phytoplankton taxa: Photosynthesis and growth of Phaeocystis Antarctica and Fragilariopsis cylindrus under different irradiance levels. Integr. Comp. Biol., 50, 950-966, doi: 10.1093/icb/icq021. [Link]

Bais, A. F., C. S. Zerefos, C. Meleti, I. C. Ziomas, and K. Tourpali, 1993: Spectral measurements of solar UVB radiation and its relations to total ozone, $\mathrm{SO}_{2}$, and clouds. J. Geophys. Res., 98, 5199-5204, doi: 10.1029/92JD02904. [Link]

Beardall, J., C. Sobrino, and S. Stojkovic, 2009: Interactions between the impacts of ultraviolet radiation, elevated $\mathrm{CO}_{2}$, and nutrient limitation on marine primary producers. Photochem. Photobiol. Sci., 8, 1257-1265, doi: 10.1039/b9pp00034h. [Link]

Becquevort, S. and W. O. Smith Jr., 2001: Aggregation, sedimentation and biodegradability of phytoplanktonderived material during spring in the Ross Sea, Antarctica. Deep-Sea Res. Part II-Top. Stud. Oceanogr., 48, 4155-4178, doi: 10.1016/S0967-0645(01)00084-4. [Link]

Buffoni, G., A. Cappelletti, and P. Picco, 2002: An investigation of thermohaline circulation in Terra Nova Bay polynya. Antarct. Sci., 14, 83-92, doi: 10.1017/ S0954102002000615. [Link]

Buma, A. G. J., P. Boelen, and W. H. Jeffrey, 2003: UVR-induced DNA damage in aquatic organisms. In: Helbling, E. W. and H. Zagarese (Eds.), UV Effects in Aquatic Organisms and Ecosystems, Royal Society of Chemistry, Cambridge, UK, 291-327, doi: 10.1039/9781847552266-00291. [Link]

Cai, W., W. Yuan, S. Liang, X. Zhang, W. Dong, J. Xia, Y. Fu, Y. Chen, D. Liu, and Q. Zhang, 2014: Improved estimations of gross primary production using satellitederived photosynthetically active radiation. J. Geophys. Res., 119, 110-123, doi: 10.1002/2013JG002456. [Link]

Dee, D. P., S. M. Uppala, A. J. Simmons, P. Berrisford, P. Poli, S. Kobayashi, U. Andrae, M. A. Balmaseda, G. Balsamo, P. Bauer, P. Bechtold, A. C. M. Beljaars, L. van de Berg, J. Bidlot, N. Bormann, C. Delsol, R. Dragani, M. Fuentes, A. J. Geer, L. Haimberger, S. B. 
Healy, H. Hersbach, E. V. Hólm, L. Isaksen, P. Kållberg, M. Köhler, M. Matricardi, A. P. McNally, B. M. Monge-Sanz, J. J. Morcrette, B. K. Park, C. Peubey, P. de Rosnay, C. Tavolato, J. N. Thépaut, and F. Vitart, 2011: The ERA-Interim reanalysis: Configuration and performance of the data assimilation system. $Q$. J. R. Meteorol. Soc., 137, 553-597, doi: 10.1002/qj.828. [Link]

Edwards, R. and P. Sedwick, 2001: Iron in East Antarctic snow: Implications for atmospheric iron deposition and algal production in Antarctic waters. Geophys. Res. Lett., 28, 3907-3910, doi: 10.1029/2001GL012867. [Link]

Fauchot, J., M. Gosselin, M. Levasseur, B. Mostajir, C. Belzile, S. Demers, S. Roy, and P. Z. Villegas, 2000: Influence of UV-B radiation on nitrogen utilization by a natural assemblage of phytoplankton. J. Phycol., 36, 484-496, doi: 10.1046/j.1529-8817.2000.99011.x. [Link]

Fu, F. X., A. O. Tatters, and D. A. Hutchins, 2012: Global change and the future of harmful algal blooms in the ocean. Mar. Ecol. Prog. Ser., 470, 207-233, doi: 10.3354/meps 10047. [Link]

Goes, J. I., N. Handa, S. Taguchi, and T. Hama, 1994: Effect of UV-B radiation on the fatty acid composition of the marine phytoplankter Tetraselmis sp.: Relationship to cellular pigments. Mar. Ecol. Prog. Ser., 114, 259-274.

Helbling, E. W., K. Gao, R. J. Gonçalves, H. Wu, and V. E. Villafañe, 2003: Utilization of solar UV radiation by coastal phytoplankton assemblages off SE China when exposed to fast mixing. Mar. Ecol. Prog.Ser., 259, 5966, doi: 10.3354/meps259059. [Link]

Hiscock, M. R., V. P. Lance, A. M. Apprill, R. R. Bidigare, Z. I. Johnson, B. G. Mitchell, W. O. Smith Jr., and R. T. Barber, 2008: Photosynthetic maximum quantum yield increases are an essential component of the Southern Ocean phytoplankton response to iron. Proc. Natl. Acad. Sci. USA, 105, 4775-4780, doi: 10.1073/ pnas.0705006105. [Link]

Jickells, T. D., Z. S. An, K. K. Andersen, A. R. Baker, G. Bergametti, N. Brooks, J. J. Cao, P. W. Boyd, R. A. Duce, K. A. Hunter, H. Kawahata, N. Kubilay, J. LaRoche, P. S. Liss, N. Mahowald, J. M. Prospero, A. J. Ridgwell, I. Tegen, and R. Torres, 2005: Global iron connections between desert dust, ocean biogeochemistry, and climate. Science, 308, 67-71, doi: 10.1126/ science.1105959. [Link]

Josefsson, W. and T. Landelius, 2000: Effect of clouds on UV irradiance: As estimated from cloud amount, cloud type, precipitation, global radiation and sunshine duration. J. Geophys. Res., 105, 4927-4935, doi: 10.1029/1999JD900255. [Link]

Karentz, D., 1991: Ecological considerations of Antarctic ozone depletion. Antarct. Sci., 3, 3-11, doi: 10.1017/ S0954102091000032. [Link]

Kropuenske, L. R., M. M. Mills, G. L. van Dijken, S. Bailey, D. H. Robinson, N. A. Welschmeyer, and K. R. Arrigoa, 2009: Photophysiology in two major Southern Ocean phytoplankton taxa: Photoprotection in Phaeocystis Antarctica and Fragilariopsis cylindrus. Limnol. Oceanogr., 54, 1176-1196, doi: 10.4319/ 10.2009.54.4.1176. [Link]

Lee, S. H., B. K. Kim, M. S. Yun, H. Joo, E. J. Yang, Y. N. Kim, H. C. Shin, S. Lee, 2012: Spatial distribution of phytoplankton productivity in the Amundsen Sea, Antarctica. Polar Biol., 35, 1721-1733, doi: 10.1007/ s00300-012-1220-5. [Link]

Minnett, P. J. and E. L. Key, 2007: Meteorological and atmosphere-surface coupling in and around polynyas. Elsev. Oceanogr. Ser., 74, 127-161, doi: 10.1016/ S0422-9894(06)74004-1. [Link]

Mitchell, B. G. and O. Holm-Hansen, 1991: Observations and modeling of the Antarctic phytoplankton crop in relation to mixing depth. Deep-Sea Res. Part I-Oceanogr. Res. Pap., 38, 981-1007, doi: 10.1016/01980149(91)90093-U. [Link]

Naud, C. M., J. F. Booth, and A. D. Del Genio, 2014: Evaluation of ERA-Interim and MERRA cloudiness in the Southern Ocean. J. Climate, 27, 2109-2124, doi: 10.1175/JCLI-D-13-00432.1. [Link]

Neale, P. J., R. F. Davis, and J. J. Cullen, 1998: Interactive effects of ozone depletion and vertical mixing on photosynthesis of Antarctic phytoplankton. Nature, 392, 585-589, doi: 10.1038/33374. [Link]

O’Reilly, J. E., S. Maritorena, B. G. Mitchell, D. A. Siegel, K. L. Carder, S. A. Garver, M. Kahru, and C. McClain, 1998: Ocean color chlorophyll algorithms for SeaWiFS. J. Geophys. Res., 103, 24937-24953, doi: 10.1029/98JC02160. [Link]

Raiswell, R. and D. E. Canfield, 2012: The Iron Biogeochemical Cycle Past and Present. Geochem. Perspect., 1, 1-220, doi: 10.7185/geochempersp.1.1. [Link]

Rienecker, M. M., M. J. Suarez, R. Gelaro, R. Todling, J. Bacmeister, E. Liu, M. G. Bosilovich, S. D. Schubert, L. Takacs, G. K. Kim, S. Bloom, J. Chen, D. Collins, A. Conaty, A. da Silva, W. Gu, J. Joiner, R. D. Koster, R. Lucchesi, A. Molod, T. Owens, S. Pawson, P. Pegion, C. R. Redder, R. Reichle, F. R. Robertson, A. G. Ruddick, M. Sienkiewicz, and J. Woollen, 2011: MERRA: NASA's Modern-Era Retrospective Analysis for Research and Applications. J. Climate, 24, 3624-3648, doi: 10.1175/JCLI-D-11-00015.1. [Link]

Robinson, D. H., Z. Kolber, and C. W. Sullivan, 1997: Photophysiology and photoacclimation in surface sea ice algae from McMurdo Sound, Antarctica. Mar. Ecol. Prog. Ser., 147, 243-256, doi: 10.3354/meps147243. [Link] 
Sass, L., C. Spetea, Z. Máté, F. Nagy, and I. Vass, 1997: Repair of UV-B induced damage of Photosystem II via de novo synthesis of the $\mathrm{D} 1$ and $\mathrm{D} 2$ reaction centre subunits in Synechocystis sp. PCC 6803. Photosynth. Res., 54, 55-62, doi: 10.1023/A:1005895924892. [Link]

Sindelarova, K., C. Granier, I. Bouarar, A. Guenther, S. Tilmes, T. Stavrakou, J. F. Müller, U. Kuhn, P. Stefani, and W. Knorr, 2014: Global data set of biogenic VOC emissions calculated by the MEGAN model over the last 30 years. Atmos. Chem. Phys., 14, 9317-9341, doi: 10.5194/acp-14-9317-2014. [Link]

Smith, R. C., B. B. Prézelin, K. S. Baker, R. R. Bidigare, N. P. Boucher, T. Coley, D. Karentz, S. MacIntyre, H. A. Matlick, D. Menzies, M. Ondrusek, Z. Wan, and K. J. Waters, 1992: Ozone depletion: Ultraviolet radiation and phytoplankton biology in Antarctic waters. Science, 255, 952-959, doi: 10.1126/science.1546292. [Link]

Smith, W. O., Jr., J. Marra, M. R. Hiscock, and R. T. Barber, 2000: The seasonal cycle of phytoplankton biomass and primary productivity in the Ross Sea, Antarctica. Deep-Sea Res. Part II-Top. Stud. Oceanogr., 47, 31193140, doi: 10.1016/S0967-0645(00)00061-8. [Link]

Sweeney, C., W. O. Smith, B. Hales, R. R. Bidigare, C. A. Carlson, L. A. Codispoti, L. I. Gordon, D. A. Hansell, F. J. Millero, M. O. Park, and T. Takahashi, 2000: Nutrient and carbon removal ratios and fluxes in the Ross Sea, Antarctica. Deep-Sea Res. Part II-Top. Stud. Oceanogr., 47, 3395-3421, doi: 10.1016/S09670645(00)00073-4. [Link]

Tagliabue, A., L. Bopp, and O. Aumont, 2009: Evaluating the importance of atmospheric and sedimentary iron sources to Southern Ocean biogeochemistry. Geophys. Res. Lett., 36, L13601, doi: 10.1029/2009GL038914. [Link]

Van Leeuwe, M. A., B. van Sikkelerus, W. W. C. Gieskes, and J. Stefels, 2005: Taxon-specific differences in photoacclimation to fluctuating irradiance in an Antarctic diatom and a green flagellate. Mar. Ecol. Prog. Ser., 288, 9-19, doi: 10.3354/meps288009. [Link]

Venables, H. and C. M. Moore, 2010: Phytoplankton and light limitation in the Southern Ocean: Learning from high-nutrient, high-chlorophyll areas. J. Geophy. Res.,
115, C02015, doi: 10.1029/2009JC005361. [Link]

Venables, H. J., A. Clarke, and M. P. Meredith, 2013: Wintertime controls on summer stratification and productivity at the western Antarctic Peninsula. Limnol. Oceanogr., 58, 1035-1047, doi: 10.4319/lo.2013.58.3.1035. [Link]

Villafañe, V. E., K. Sundbäck, F. L. Figueroa, and E. W. Helbling, 2003: Photosynthesis in the aquatic environment as affected by UVR. In: Helbling, E. W. and H. Zagarese (Eds.), UV Effects in Aquatic Organisms and Ecosystems, Royal Society of Chemistry, Cambridge, UK, 357-397, doi: 10.1039/9781847552266-00357. [Link]

Wadham, J. L., M. Tranter, M. Skidmore, A. J. Hodson, J. Priscu, W. B. Lyons, M. Sharp, P. Wynn, and M. Jackson, 2010: Biogeochemical weathering under ice: Size matters. Global Biogeochem. Cycles, 24, GB3025, doi: 10.1029/2009GB003688. [Link]

Yager, P. L., R. M. Sherrell, S. E. Stammerjohn, A. C. Alderkamp, O. Schofield, E. P. Abrahamsen, K. R. Arrigo, S. Bertilsson, D. L. Garay, R. Guerrero, K. E. Lowry, P. O. Moksnes, K. Ndungu, A. F. Post, E. Randall-Goodwin, L. Riemann, S. Severmann, S. Thatje, G. L. van Dijken, and S. Wilson, 2012: ASPIRE: The Amundsen Sea Polynya International Research Expedition. Oceanography, 25, 40-53, doi: 10.5670/oceanog.2012.73. [Link]

Yuan, W., Y. Luo, X. Li, S. Liu, G. Yu, T. Zhou, M. Bahn, A. Black, A. R. Desai, A. Cescatti, B. Marcolla, C. Jacobs, J. Chen, M. Aurela, C. Bernhofer, B. Gielen, G. Bohrer, D. R. Cook, D. Dragoni, A. L. Dunn, D. Gianelle, T. Grünwald, A. Ibrom, M. Y. Leclerc, A. Lindroth, H. Liu, L. B. Marchesini, L. Montagnani, G. Pita, M. Rodeghiero, A. Rodrigues, G. Starr, and P. C. Stoy, 2011: Redefinition and global estimation of basal ecosystem respiration rate. Global Biogeochem. Cycles, 25, GB4002, doi: 10.1029/2011GB004150. [Link]

Yue, X., N. Unger, and Y. Zheng, 2015: Distinguishing the drivers of trends in land carbon fluxes and plant volatile emissions over the past 3 decades. Atmos. Chem. Phys., 15, 11931-11948, doi: 10.5194/acp-15-119312015. [Link] 